\title{
A STUDY OF REFLECTANCE SPECTRUM OF NASAL MUCOSAL PATHOLOGY
}

\author{
SHIGERU FURUTA, M. D.
}

Department of Otolaryngology, Kagoshima University, Faculty of Medicine, Kagoshima

An analysis concerning the mucosal color and its pathophysiological significance was made on 24 normal subjects and 28 allergic patients using refectance spectrophotometer system which was designed and manufactured for the present report. The results obtained were as follows;

1) By analyzing the reflectance spectra of Munsell's Color Standards, it was proved that the charactristics of the different colors coule be readily determined.

2) In normal subjects, there were three main positive waves of the spectra: the peak at around $500 \mathrm{~nm}\left(\mathrm{P}_{1}\right)$, the smallest at around $560 \mathrm{~nm}\left(\mathrm{P}_{2}\right)$ and the highest one at $660 \mathrm{~nm}\left(\mathrm{P}_{3}\right)$.

3) It was found that the spectral peak of $\mathrm{P} 3$ in patients with nasal allergy, when compared to that of normal subjects, shifted remarkably toward the shorter wavelength at around $640 \mathrm{~nm}$ and the increment of the absorption band at around P2 was also observed.

4) Markedly decreased hight of P2 wave was seen in chronic sinusitis. A flat pattern of the entire spectra was seen in nasal polyp

Reflectance spectrophotometric analysis is highly useful as a non-invasive and objective method not only to record the color of nasal mucosa but also to evaluate the mucosal pathophysiology of the upper airway.

\section{A86-0761-30891}

\section{鼻粘膜病態の反射光スペクトル解析による矿究}

一 II 色調と光スペクトルの関係

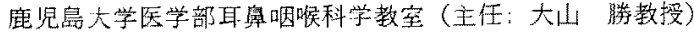

古旦茂

$$
\text { I はじめに }
$$

學副悬啌のみならず，疾病の本態を解明する場合，病

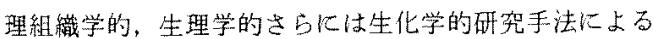
アプローチが基本となることは言うまでむない。しか

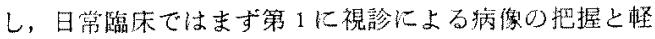
重の判定加最屯多用され，その臨床診断上の価值は，今 日でも依然として大きい，特に，耳鼻咽喉科領域の診療

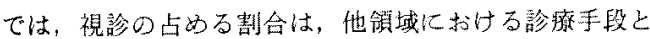

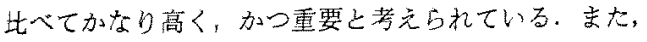
病变に打ける色調の調化は，珠状の变化などとともに，

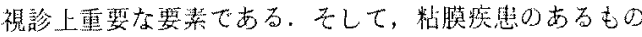
は色調の变化方彰断の根趑となり得ることが少なくな

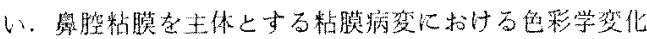

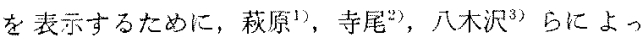

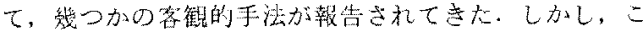

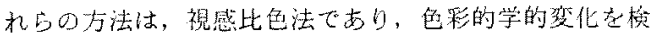
者の経愿で上らえる表示法としては有用と思われるが，

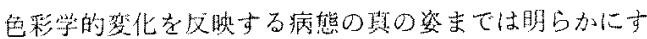
るに至らなかった。

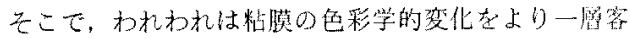




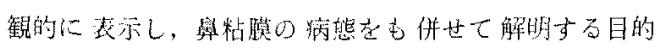

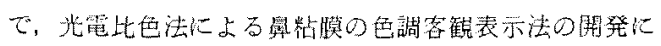

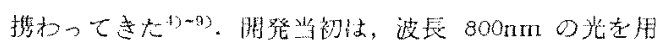

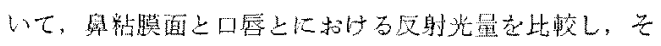

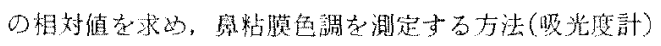

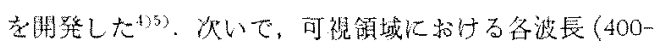

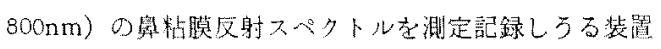

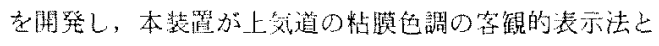
して厚れ，また，乙の病態をも解明する有用な手段とな りらることな示咥した scanning 時間か30秒上長く, optic fiber 粘膜面に接 着できないことが欠点よして指摘され，改具の必要があ $=$ t.

そのため，今回著者は，促来の上気道炶膜反射不心ク トル装置比改度を加え，さらにコンピュータ一解析法を 導入まるこ上により，計測時間方短々，多時間表示法の 行い得る粘膜反身スペタトル菱置を用発した。てして， 本装置を用いて基䝪的检討ならびに臨床心用を試みた結 果，若干の興味ある新知見が淟られたのてここに赫告す 万.

\section{II 上気道反射スペクトル解析装置 \\ 1) 原理}

艺が物体に投射される上，光の一部は丠面的射し，残

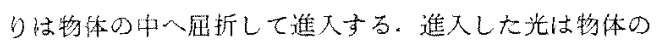

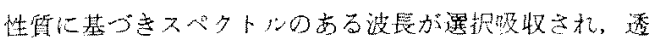

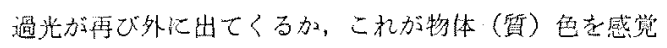
させるのである，正して，投射した光の可視波長全域に

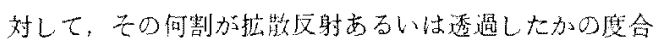

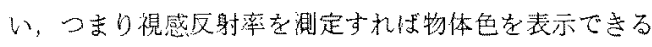

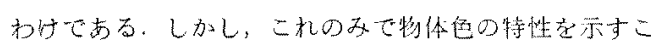
上は，基枆上大る投射光が安定していて，しかもをれが

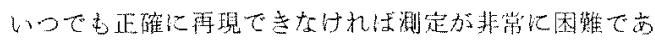

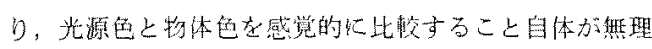

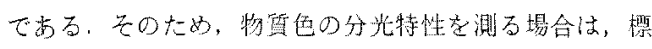

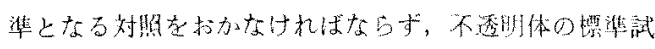
料としては，梘感反射率吕可得波長全域に对して約97.5 \%を小酸化マグホシわム（MgO）がdいとされてい

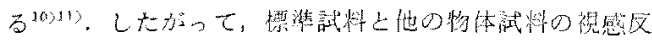

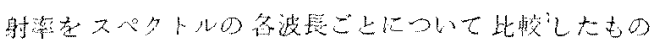

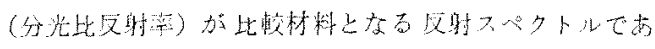

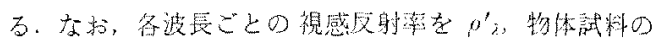

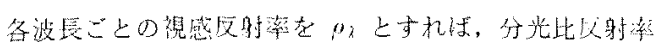

Table 1 Intra- and extra-cellular biological pigments.

Hemoglobin: $\mathrm{Hb}-\mathrm{O}_{2}, \mathrm{Hb}, \mathrm{HbCo}$,

Myoglobin: $\mathrm{Mb}-\mathrm{O}_{2}, \mathrm{Mb}, \mathrm{MbCo}$,

Cytochromes: mitochondrial $a(a), b(b r), c_{1}, c$ microsomal $b_{3}, p-450$

Hydryperoxide: catalase, peroxidase

Flavoproteins

Pyridine nucleotide

Bile pigments: bilirubin, biliverdin, urobilin etc.

Porphyrin: proto-uro-, copro-porphyrin etc.

Carotenoid

Ferritin, Homosiderin etc.

$\mathrm{Y}_{\lambda}$ との間には， $\mathrm{Y}_{\lambda}=\rho_{\lambda} / \rho_{\lambda}^{\prime}$ の閔係がある。

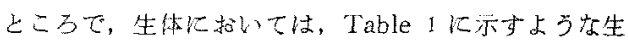
体酜素ないしは，色素が光の吸収，反射の役目を演して いる。粘膜に颣ては，主として血液中の hemoglobin

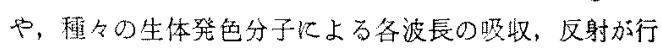
われ，午の結果特有の色調を品しているわけである.こ れらの物俱样々な機能学んているので各種病態儿応 じてその墈きに変化が起きることは十尔想像される。そ

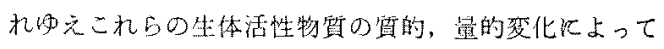
生ずる反射波舆の相掘を記録測定することは，粘膜色調

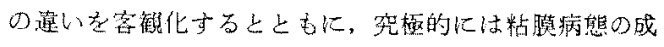
因の一端䘮解明しうる可能性がある。

2) 測定㱔䇫

本装置はマルチチャンネル分光测定法老生体测定に応

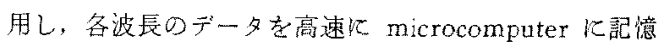

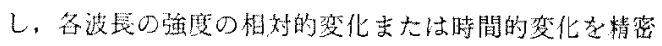
に測定しうるものてある(Fig，1).

Fig. 2 はその block diagram を示している. 光源 (UL-005, ヨーソランプ100W) より出た光は, optical

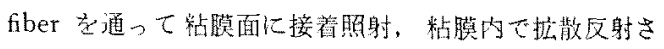

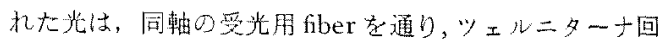

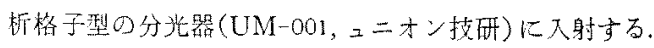
この人射范は分光器で分光さ礼 MCPD (multichannel photo detecter) 换出盟上に band spectrum として各 波長比分加机て集光才石。MCPD㛟出器は photo diode

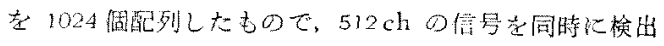
するこ上加可能でる。この素子から得方九大枌出信号 は, control 回路老経て, microcomputer $D$ memory 


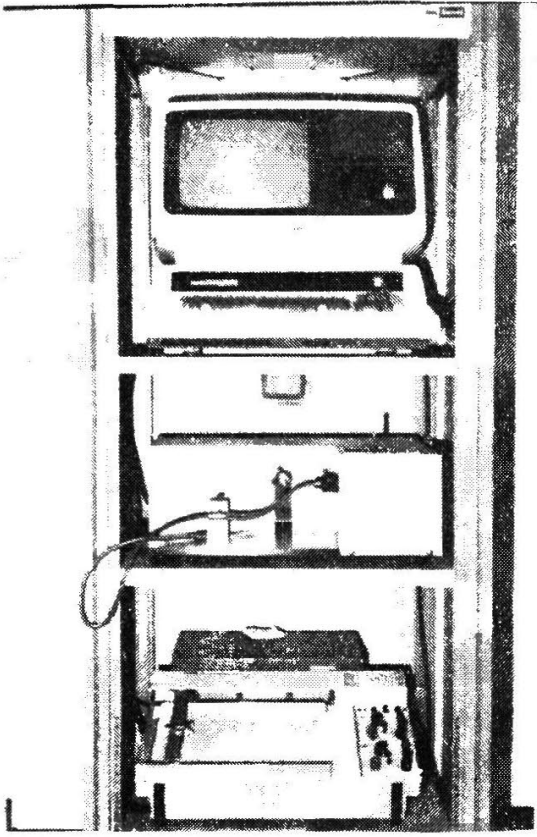

Fig. 1 Reflectance spectrophotometric system.

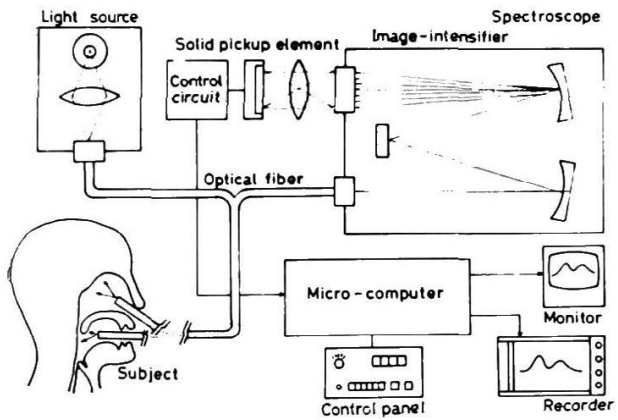

Fig. 2 Block diagram of reflectance spectrophotometric system.

に記憶され，演算処理をした後に moniter に表示し， また, XY recorder（RA-452，ユニオン技研）に出力 することが可能である.

3）測定方法

被検者は耳鼻咽喉科㟝察用椅子に安静に座らせ, 頭部 は固定した。直径 $3 \mathrm{~mm}$ の fiber の先端を静かに下鼻 甲介の粘膜面に接着させ, 反射スペクトルを測定した. あらかじめ鼻粘膜と対比させるために, 基準物質として

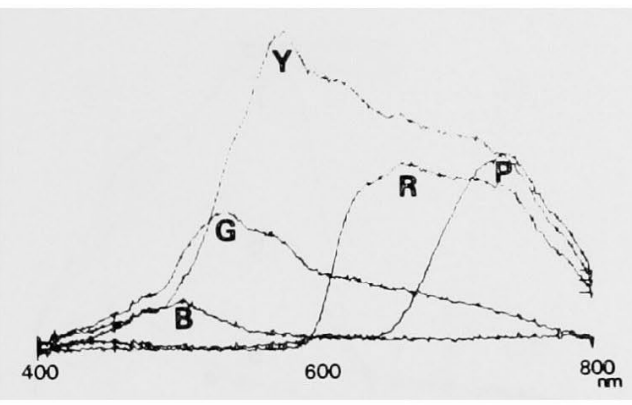

Fig. 3 Reflectance spectra of Munsell's color-sheets. R-red, Y-yellow, Ggreen, $\mathrm{B}$-blue and $\mathrm{P}$-purple.

$\mathrm{MgO}$ を選択し，その反射スペクトルを測定し， memory させた上で，個々の丼粘膜の分光比反射率曲線（以下粘 膜反射スペクトルと呼ぶ）を測定した．また，同時に演 算処理により分光比透過率曲線 (以下粘膜吸収スペクト ルと呼ぶ）も検出した． $400 \mathrm{~nm}-800 \mathrm{~nm}$ の波長領域を scanning する時間は $20 \mathrm{msec}$ に設定した.

\section{III 研 究 成 績}

1） マンセル色標の反射スペクトル

マンセル色標とは, 1927年 A. H. Munsell により発 案された記号汇より表示する色標で, 現在使用されてい るものは, その後アメリカ光学会 (Optical Society of America）の測色委員会が初版の感覚的な等歩度の不規 則性を改良したものである ${ }^{10)}$.

著者は粘膜反射スペクトルを調ベる前に，基嘫的実験 として, 従来より, 視感比色法に使用され有用性の認め られているマンセル色標を用いて, その色の三属性の異 なる色標について, それぞれ反射スペクトルとの対応を 試みることにより, 本装置の色彩学的表示法の妥当性の 可否を検討した. Fig. 3 は色相の变化を反射スペクトル にて表示したものである．色相は，スペクトルの各単色 光の刺激に対して, 短波長加ら長波長に移動するにつれ て, その色觉の色調順飞紫, 青, 緑, 黄, 橙, 赤と抽象 表現するものである.そのため，物体の色が青であれば その物体は短波長光を拡散反射し, その反対に, 赤であ れば，その物体は主として長波長光を拡散反射すること になる.今回選択した 5 種の色標は, その性質からする と, 短波長域から紫, 青, 緑, 黄, 赤の順に反射光が得 られなければならない，その反射スペクトルを検討する と, 紫を除く4種の色標はその性質に対応した成綪が得 


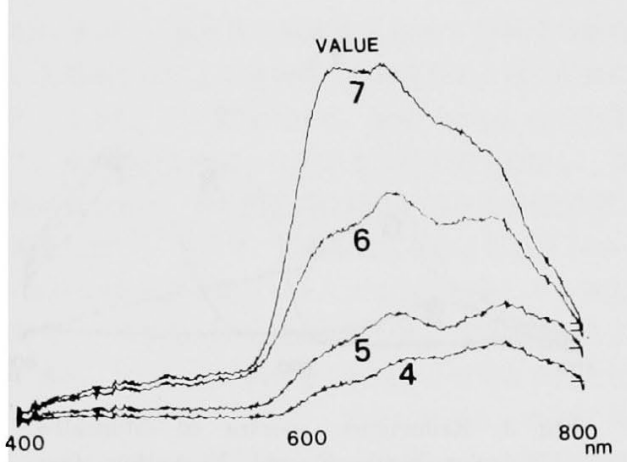

Fig. 4 Reflectance spectra of Munsell's color-sheets. (Hue- 5 RP, Chroma-8)

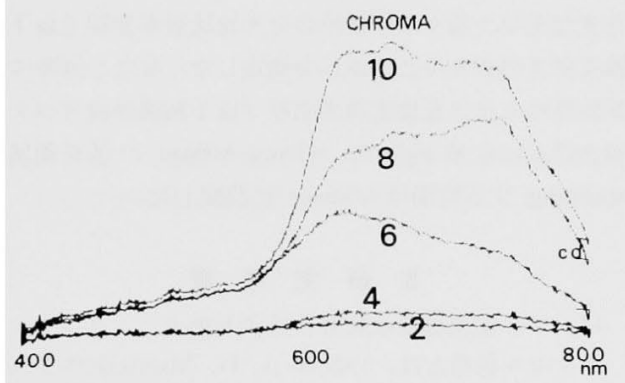

Fig. 5 Reflectance spectra of Munsell's color-sheets. (Hue-7, 5RP, Value-5)

られた。この結果は，紫の反射光が得られる 400nm 付 近では，本装置の fiber および光源に特性上，測定限界 と考えられた。

Fig. 4 は色相 5RP, 彩度 8 の色標の中から明度の差 を認める 5 枚の色標を選択し，反射スペクトルを測定し たものである．明度 6 までは，650nm と $750 \mathrm{~nm}$ 付近飞 peak を保ちながら, その反射域值は上昇傾向が認めら れる，明度 そでは，620nm付近の反射域值が強まり，反 射波形に变化が認められた. 光が多量に眼に入射すれば それだけ明るい感覚を生じ，この明るさの感覚を定量化 したあのが明度である。エネルギースペクトルをみた場 合, われわれの眼は中波長光を最も明るく感じ, 一方, 短, 長波長光では暗く感ずるとされている，したがっ て，Fig， 4 に示す peak 值の中波長域での增加は，明度 の变化を忠実に反映していると理解できる.

彩度と反射スペクトルの関係を検討すると，彩度の变 化は反射域值の上㫒という形で認められ，ほぼ規則性を

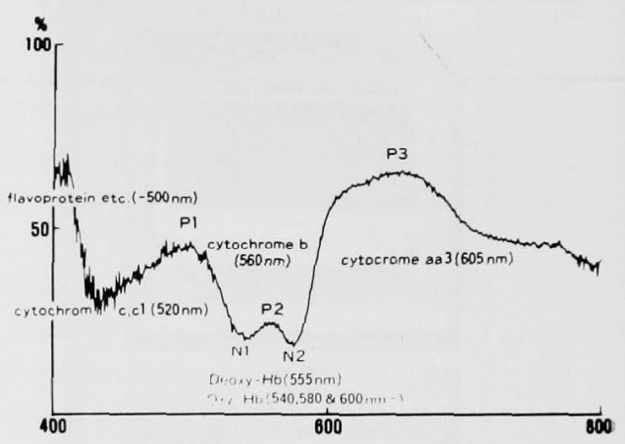

Fig. 6 Reflectance spectrophotometric curve of nasal mucosa in normal human adult.

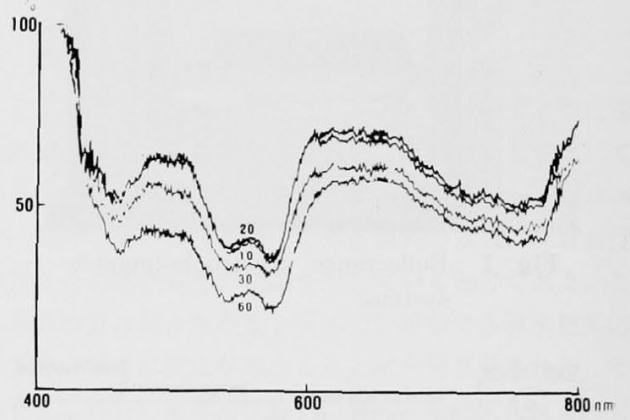

Fig. 7 Reflectance spectrophotometric curve of nasal mucosa following nasal spray with decogestant.

持つものと考光られた（Fig. 5).

2）ヒト鼻腔粘膜反射スペクトル

a）正常者の鼻粘膜反射スペクトル

Fig. 6 は正常成人の下宜甲介粘膜の反射スペクトル を示している，その波形は，3つの陽性波（以下P波） と 2 つの陰性波 (以下N波) が認められ、P波は500nm (以下 $\mathrm{P}_{1}$ ), $560 \mathrm{~nm}$ (以下 $\mathrm{P}_{2}$ ), 660nm (以下 $\mathrm{P}_{3}$ ) 付近 に peak を示し, N波は $540 \mathrm{~nm}$ (以下 $\mathrm{N}_{1}$ ) と $580 \mathrm{~nm}$ (以下 $\mathrm{N}_{2}$ ) 付近に認められた。

次いで，正常者下鼻甲介粘膜に血管収縮剤を 1 回噴霧 し，薬剤の齅粘膜に及ほす影響について反射スペクトル を用いて検討した、その結果, 反射スペクトル波形は韻 霧により各波とも域值の上昇を示し, 10分後にその peak を示した，以後泍减傾向を示し，貲蓩60分後にはほほ噴 霧前の状態に回復した. それに伴って $\mathrm{P}_{3}$ の波長位置は 10分後には, 著明に左方移動を示し, その後には噴霧前 
10

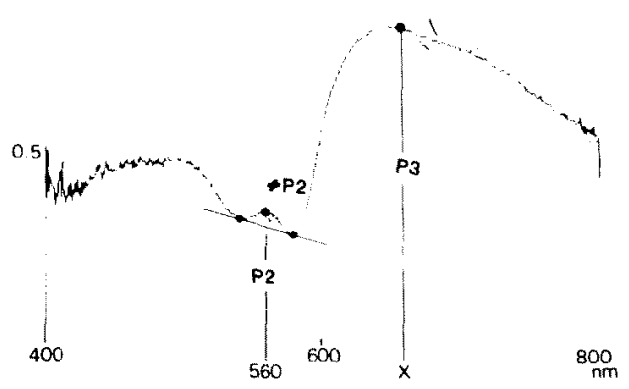

Fig. 8 Parameter of reffectance spectrophotometric curve. (\#P2: $\left.\triangle \mathrm{P} 2\left[\mathrm{~N}_{1}-\mathrm{N}_{2}\right]\right)$

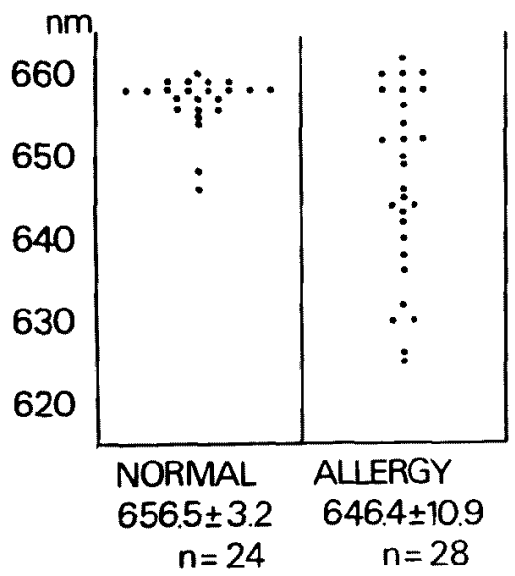

Fig. 9 Comparison of mean value of each wavelength in the spectral peak between normal subjects and patients with nasal allergy

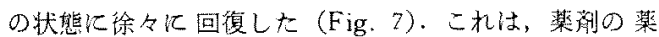
理学的作用上隹ほ一致した。したが。て、各摽本間の比

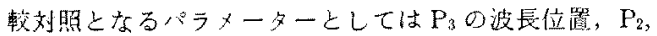

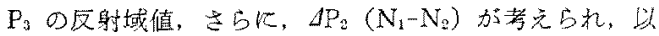
下こ扎のハラォーターについて检索した（Fig，8）。

b) 楀アレルギー患者の粘膜反射スペクトル

正学人 24例上舅アレルギ一慗者28例を对象として反

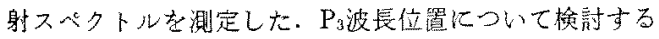
之，正常者群の平均倠は $656.5 \pm 3.2 \mathrm{~nm}$ ，與アレルギー

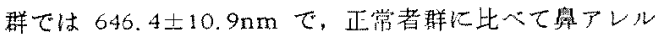

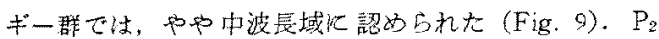
の反射域值は正常者群比バて門アレルギ一群ては著し

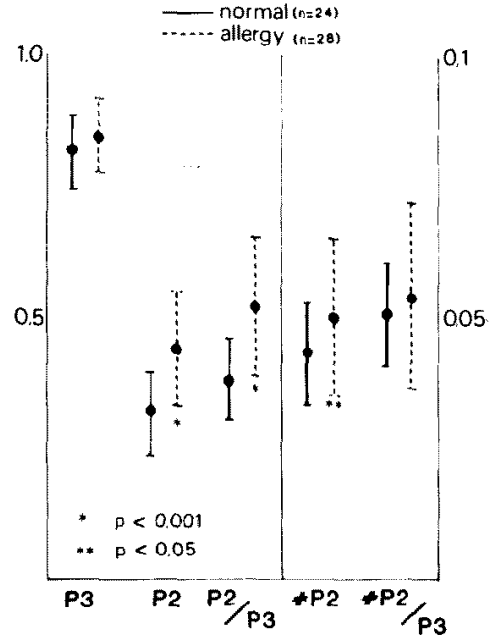

Fig. 10 Comparison of peak value $\left(\mathrm{P}_{2}\right.$ and P3) in normal and allergic subjects.
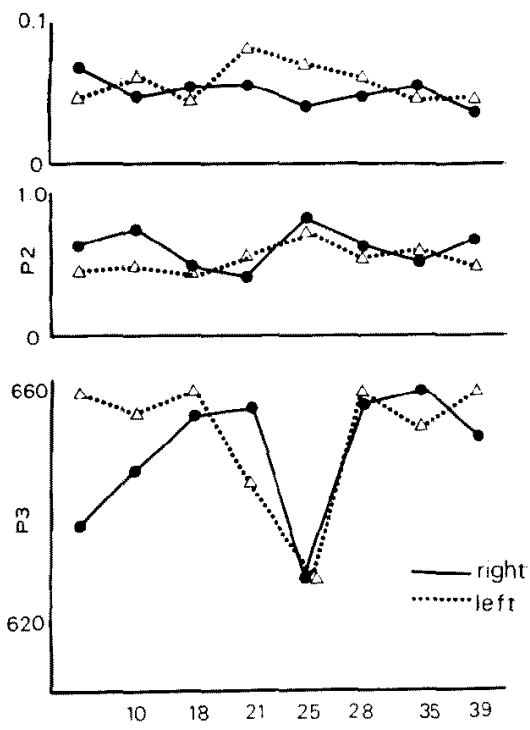

Fig. 11 Comparison of parameter reflectance spectrophotometric curve in the patient with nasal allergy.

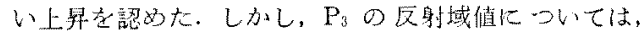
雨群の問に有意の筮は諗的られな加った。 $\Delta \mathrm{P}_{2}\left(\mathrm{~N}_{1}-\mathrm{N}_{2}\right)$ は，正常群に比ベて舅アレルギ一群がわずかに高い傾向

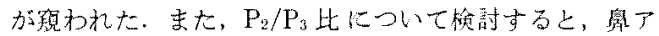




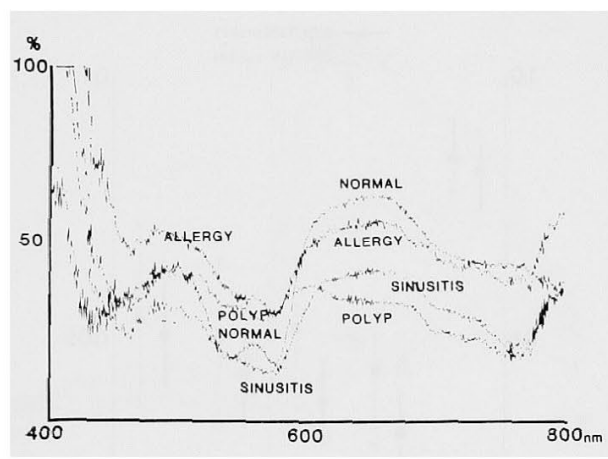

Fig. 12 Reflectance spectrophotometric curves of nasal mucosa comparison with normal, allergy, sinusitis and polyp.

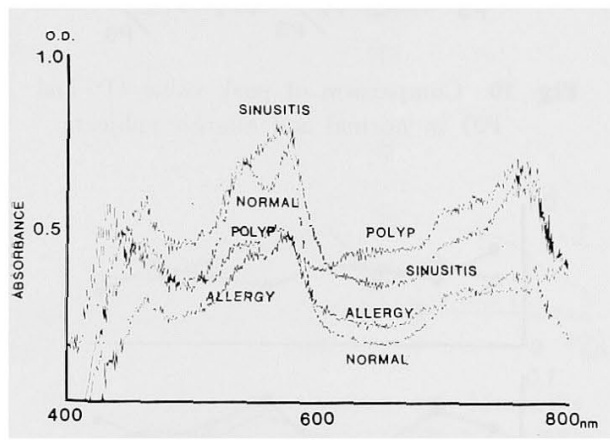

Fig. 13 Reflectance spectrophotometric curves of nasal mucosa comparison with normal, allergy, sinusitis and polyp.

レルギー群では正常者に此へて有意们高値を示し，舅了 レルギー患者の粘膜反射スペクトルは正常者に比べて平 坦化の傾向が窥われた。 $\Delta \mathrm{P}_{2}\left(\mathrm{~N}_{1}-\mathrm{N}_{2}\right) / \mathrm{P}_{3}$ 比については, 両群化有意の差を認めなかった（Fig. 10）。

上記鼻アレルギー患者群の中で，1力月有余の期間粘 膜反射スペクトルルよる経過老観察し得た 1 症例を供臨 する。

症例: M. I, 35歳, 女性.

2 年前より通年性にくしゃみ発作, 鼻閉, 水様性鼻汁 の症状を来す, 初診時, 前鼻鏡所見では右側與腔粘膜は 荟白で浮腫状に腫脹していた。しかし，左側舅腔粘膜は やや発赤を認める程度であった、舅汁检查で好酸球陽性 （十）ながら，皮内反応招よび誘発試験飞て特異抗原が 判明しないため, 同日より週 3 日のリノビンによるネブ ライザー療法を開始した。それにより, 症状は軽快し

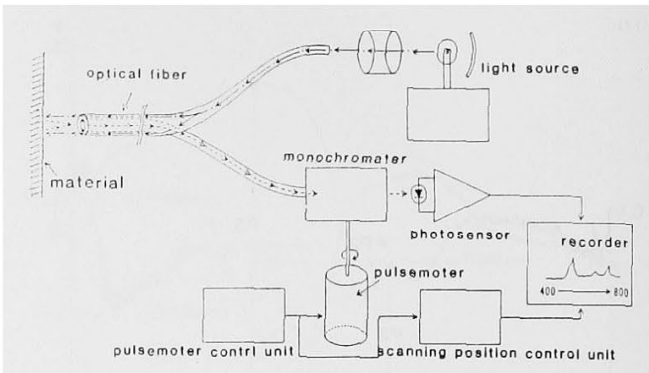

Fig. 14 Block diagram of fiber optic spectrophotometer.

た.しかし21日目より症状の再燃があり，25日目には， その症状は極期に達し, 前鼻鏡所見でも両側下甲介は蒼 白で浮腫状に腫脹していた。 そして, その後除々に回復 し，39日目には症状は軽快した，反射スペクトルルよる 佮查成績では（Fig. 11)，特に最下段の $\mathrm{P}_{3}$ 波長位置と 中段に示す $P_{2}$ 反射域值が，忠者の症例，所見にほほ 致することが判明した。

c）その他の疾患における反射スペクトル

慢性副鼻舡炎患者の反射スペクトル波形について検討 すると, 各P波の域値の低下が認められた，その中で， $\mathrm{P}_{\mathrm{a}}$ 波形の消失が特徴的であった，また粘膜反射スペク トルでは, 各波長に拈ける反射域值が均一化し, 各波の 消失を認め, 波形の平坦化の傾向が認められた。下鼻甲 介粘膜から得られた波形とは，全く異質なものとなった (Fig. 12).

\section{d) 吸収スペクトルの㭘討}

吸収スペクトル波形は，反射スペクトルを求める際 に，演算処理にて算出することができる．その波形は， 反射スペクトルとほほ鏡像を呈した形を示し，鼻腔内粘 膜における吸収スペクトルでは，540nm から580nm に 及ぶ波長領域の変化が主体であった（Fig，13）。

\section{1）䒾置の開発の経禕}

1934年, Bernheimer Kよって始まった，鼻粘膜色調 に関する咞究は, 従来より数多くの研究が行われてい る.しかし，その多くは視感比色法による屯のであっ

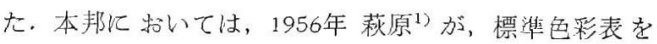
用いて, 正常者と舅副䁷腔疾患患者の嶴腔粘膜の色彩学 的観祭を試み, 併せて, 病理組織学的検索成績とを比洨 した. そして, 寺尾”は, 修正マンセル色標を用いて, 
正常者の下率甲介およひ舆中倩粘膜について視感比色的

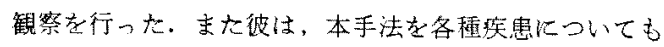
応用したが，視感比色法がその信頼性中客観性の面で俈 外に之しいことを指摘し，色調の研究には，光霓此色法 を行うへきこ上を推奖した。八本沢もまた修正マンセ儿

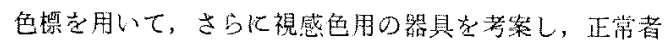
と各種䁷矣患に対して，下舆妇介先端部を对照として視

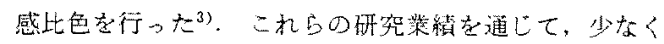
と正視感比色法を用いた舉粘膜の色彩学的表現は一应明 確比されたとい方。

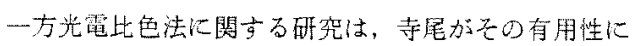
ついて冁告しているが，その成暴を出すまてには至らな 加っだ, 表た, 野村 ${ }^{132}$ は, fiber optic oximeter いて，正常，ビデアン神経切断徣，木儿ネル症候群执よ

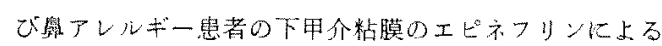
蒼白化について記録花している。われわれの教空では，

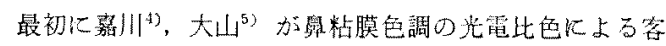

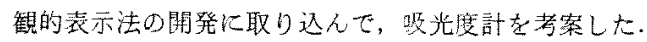
これは，粘膜色が，主に䏣色素よより左右されることに 着目したものですり，血色素の吸光度が $800 \mathrm{~nm}$ にて酸 化机上び還元 hembglobin が等電点に達することを心

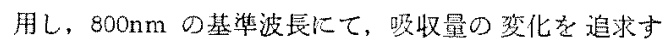
るものである．この方法を用いて，口唇を対照として鼠

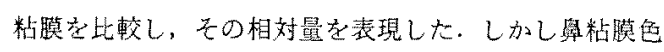
調な゙具現する要菜は，血色素のみではなく，Table 1。沉

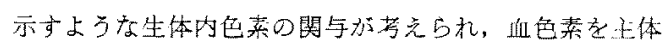
とした方法ては，正確な色調の表現上なり得な加った。 そのため，可視領域の各波辰比括ける反身スペクトルを

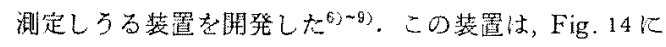
示すように，白色光支集光後，fiber 一端にて粘膜面を

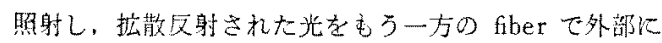

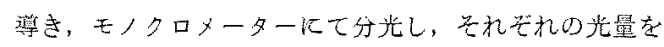
$\mathrm{Y}$ 軸に，一方波是位置をX韩に連続的に記録するもので

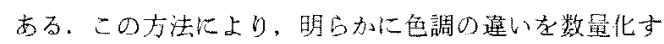
ることが可能となり，また，各種病態像を色彩学的立場 から定性表示する成績が得られるようになった。加 し，粘膜内ての生体内色素の動態をて追求することは，

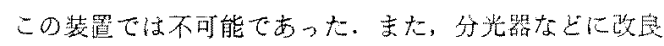
の余地があった。 そのためこれらの短所在改度す心 く, 分光器の性能を上げ, 演算処理にマイコンを就入

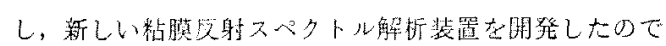

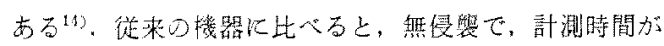

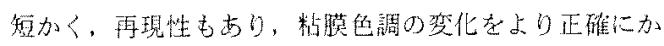

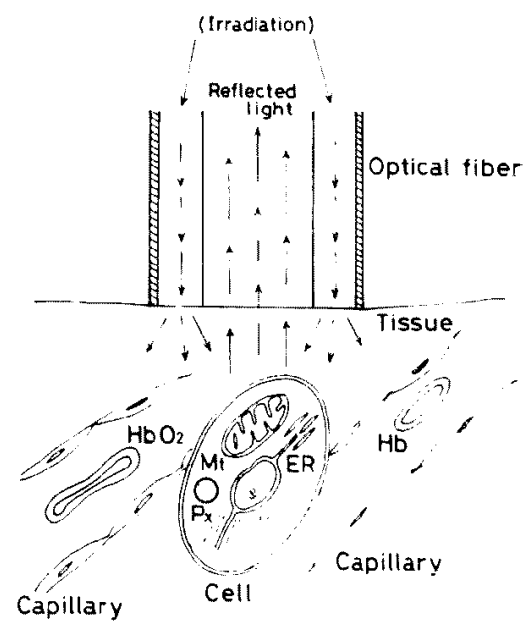

Fig. 15 Schematic illustration of the reflectance spectrophotometric analysis applied to the nasal mucosa.

つ詳細に解析可能なものてある。またはほ同時期に，

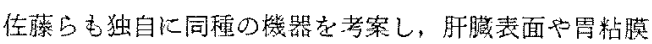

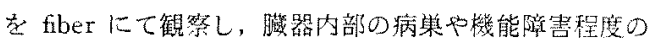
解明に取り組み，幾つかの興味ある業績を世に問うてい $z^{5-3)}$.

\section{2）舆粘莫の区射スベタトル浪形}

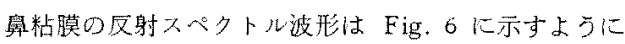
$500 \mathrm{~nm}\left(\mathrm{P}_{1}\right), 560 \mathrm{~nm}\left(\mathrm{P}_{2}\right)$, 660nm $\left(\mathrm{P}_{3}\right)$ にみb机る 3 理の陽性波と， $540 \mathrm{~nm}\left(\mathrm{~N}_{1}\right)$ と $580 \mathrm{~nm}\left(\mathrm{~N}_{2}\right)$ 飞示す 2

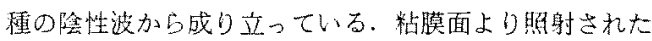
光は，組織内にて搪散反射され，一部は吸取され，一部 は組織外にて反射さ狄る（Fig，15）。本装䠄はこの反射 光を観䋈するのてあるが，反射せず一部吸収された波舆 带が，その組織内での生体内色素の䣦態交与屯のと考

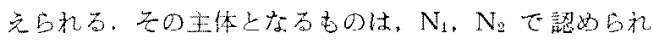

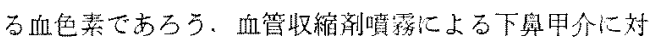

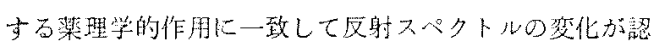
めら社たこ上より，この成分植色菜由来のものでる

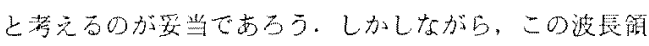

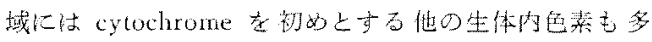
数吸収带を持つため，その波形の变化す心てが血色素由 来のもの上断定すること沽不时能てある。

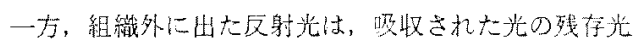

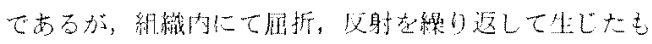


のである、しがって，その波形は内部橉筑や表面權造の

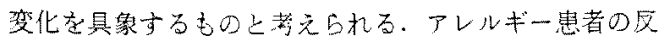

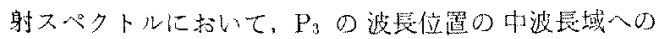

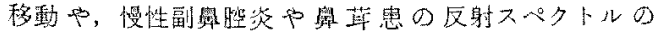
pattern の乱秃はをの事害真体的に提示しているもの であるろ、

以上の成績により，本装置は，鵕此膜色調の客锥的表 示法としては，他に類をみないものといえよう。また， 古の反射スペクトルを解析することにより，色調の变化

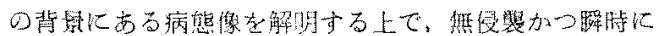
極めて有用な情啹を与えてくれる診断手法でもある。

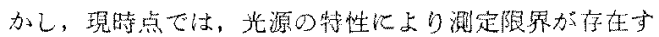
るため、レーザー光など数しい光源のの使用の闒题が注

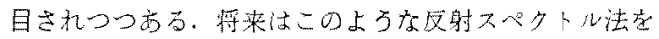

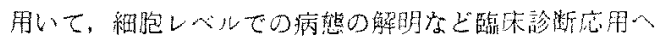
の課題が大いに期待されるところである。

$$
\mathrm{V} ま\llcorner\varnothing
$$

新しい炶膜反射スハクトル装置を開発し，基檚的，臨 本的检討を加えた結果，次の成績加得巨れた。

1。修正マンセル色標の反射スペクトルはそれそれの 色彩学的离化在活忠䒠加つ䛨緗化具現した。

2.七下下粤甲介粘膜反射スペクトル波形は，300 陽性波と2つの愫性波莸椿成していた。

3. 反射スパクトルの比較対照となるパラメーターと

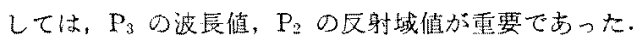

4. 正勒者 24例と鼻了レルギ一患者 28例について反

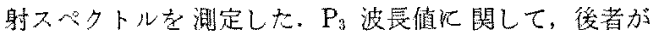

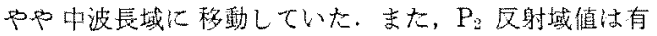
意俚上昇していた。

5. 慢性副舅空炎㭧者の反射スペクトルでは P 波形 の消失が琶好られた。

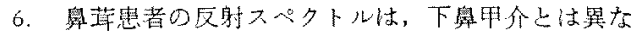
り平坦化傾向方諗められた。

7. 本装䇫は，站膜色調の客観的表示法として圂れて

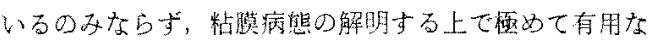
手法である。

\section{参考文献}

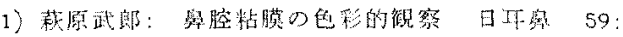
$1858-1898,1956$

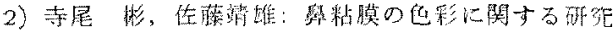
日年奥 78: 501-507，1975。

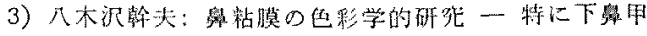
介の微察—耳䃆 20: 164-179, 1977.

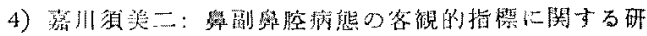

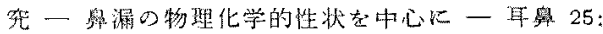
$725-739,1979$

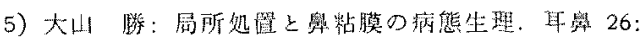
$754-760,1980$.

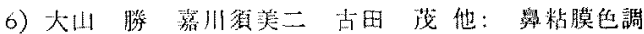
○客観的表示法一反射スペクトル解析による新し

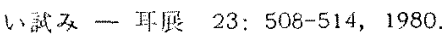

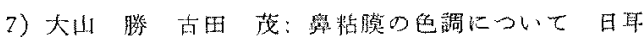
级 $84: 926-929,1981$.

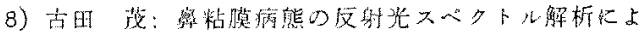

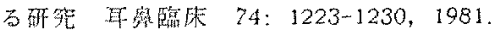

9) Ohyama M, Furuta $S$ and Hanamura $Y$ et al: Functional morphology and biochemistry of the nasal mucosa, Rhinology 21: in press, 1983.

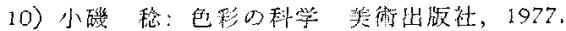

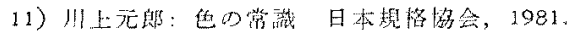

12) Bernheimer $L$ B: Color index of nasal septum. Arch Otolaryng 59: 461, 1953.

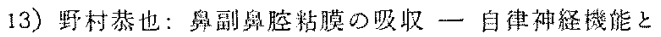
吸收烏受 21:841-844, 1975 .

14) Ohyama M, Furuta $S$, Yano $H$ et al: Rellectance spectrophotometric studies on mucosal pathology of the upper airway. Laryngoscope 92: 1168$1172,1982$.

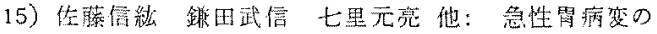

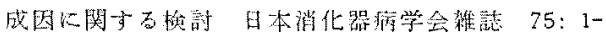
7,1978 .

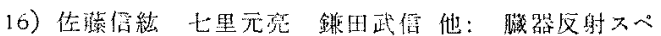

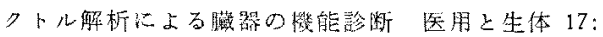
538-544, 1979 .

17) Sato N, Kamada $T$, and Shichiri $M$ et al: Measurement of hemoperfusion and oxygen sufficiency in gastric mucosa in vivo. Gastroenterology $76 \quad 814-819,1979$

18) Sato N, Shichiri $M$ and Hayashi $N$ et al Behavior of cytochrome oxidase in living liver tissue direct analysis of turnover of cytochrome na3 in liver in situ by reflectance spectrophotometry. Cytochrome Oxidase 319-329, 1979.

19）清水蓕一光汭オテレメトり医用上生体 18 
$492-498,1980$

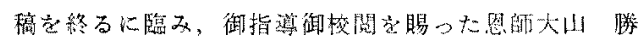

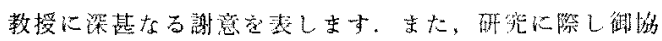

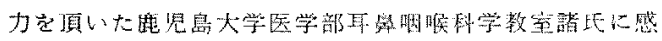
謝璬します。

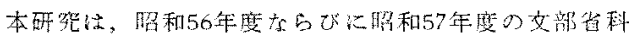

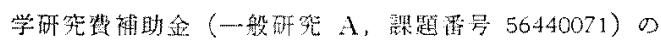

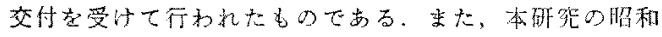

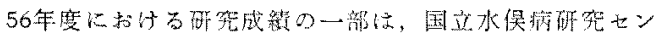

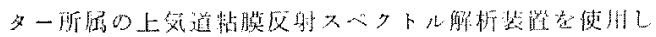
て得られたものでるるここに煙して感謝する。

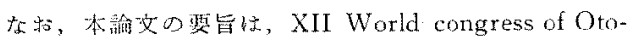
Rhino-Laryngology (Budapest), 第20回，第21回日本率

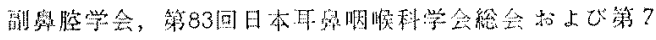

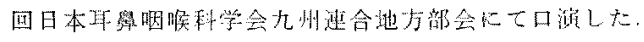

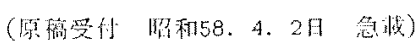

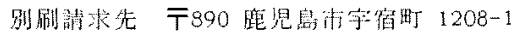

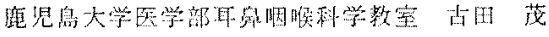

